\title{
IPTEK Bagi Masyarakat Perbaikan Teknologi Pengolahan Jagung bagi Kelompok Wanita Tani di Kecamatan Kutasari, Purbalingga
}

\author{
Nur Aini ${ }^{\# 1}$, Budi Sustriawan ${ }^{\# 2}$, Masrukhi*3 \\ \#Program Studi Ilmu dan Teknologi Pangan Universitas Jenderal Soedirman \\ Jalan Dr. Soeparno, Purwokerto \\ ${ }^{1}$ email.nur.aini@unsoed.ac.id \\ ${ }^{2}$ email.budi.sustriawaneunsoed.ac.id \\ *Program Studi Teknik Pertanian Universitas Jenderal Soedirman \\ Jalan Dr. Soeparno, Purwokerto \\ 3email.mrukhi@gmail.com
}

\begin{abstract}
KWT Enggal Sukses dan KWT Mekar Sari merupakan kelompok afinitas yang bergerak dalam mengolah potensi lokal, terutama jagung. Tujuan kegiatan pengabdian kepada masyarakat ini adalah memperbaiki teknik pengeringan, meningkatkan produktivitas kelompok dengan cara mengenalkan dan mempraktekkan produk olahan dari tepung jagung, serta memperbaiki teknik pengemasan, pelabelan dan penyimpanan produk olahan jagung. Metode yang digunakan berupa penyuluhan, praktek dan pendampingan dengan materi meliputi cara memproduksi pangan yang baik, pengolahan tepung jagung menjadi mi jagung, cara pengemasan dan pelabelan produk olahan makanan yang benar dan memenuhi standar mutu serta teknik pengeringan pada bahan pangan. Kegiatan Iptek bagi Masyarakat ini telah meningkatkan kualitas dan kuantitas hasil pengeringan dengan cara memperbaiki teknik pengeringan pada pembuatan beras jagung instan dan tepung jagung di kelompok mitra yaitu dengan adanya pengering buatan. Kelompok juga telah mengenal olahan baru dari tepung jagung, yaitu berupa mi jagung. Kemasan beras jagung instan dan tepung jagung lebih menarik dan penyimpanan produk telah diperbaiki.
\end{abstract}

Keywords - Jagung, pengolahan, pengeringan, pengemasan, penyimpanan

\section{Pendahuluan}

Jagung merupakan salah satu komoditas andalan di Kabupaten Purbalingga dengan area penanaman pada tahun 2014 seluas 5861 ha dan jumlah produksi 32.011 ton. Salah satu sentra produksi jagung di Purbalingga adalah di Kecamatan Kutasari, yang memiliki areal penanaman jagung seluas 958 ha dan jumlah produksi pada tahun 2014 sebesar 5392 ton. Rata-rata produksi jagung di Kecamatan Kutasari ini sebesar 56,28 kuintal per hektar, lebih tinggi dibanding rata-rata produksi di Kabupaten Purbalingga, yaitu 54,62 kuintal per hektar.

Berdasarkan nilai gizinya, kandungan protein jagung, baik jagung putih $(10,36 \%)$, maupun jagung kuning $(9.5 \%)$ lebih tinggi daripada beras giling $(6,69 \%)$. Sedangkan dari sisi gizi yang lain, yaitu mineral dan vitamin, komposisi beras dan jagung hampir sama, bahkan jagung kuning mempunyai keistimewaan karena adanya kandungan pro vitamin A yang tidak terdapat dalam beras ${ }^{[1]}$.

Tingginya produksi jagung di Kecamatan Kutasari menggerakkan beberapa kelompok wanita tani melakukan kegiatan pengolahan jagung, diantaranya Kelompok Wanita Tani (KWT) Mekar Sari dan KWT Enggal Sukses. KWT Enggal Sukses terletak di desa Karangcegak, Kutasari yang merupakan salah satu desa sentra jagung yang telah dicanangkan untuk menjadi Desa Mandiri Pangan melalui Program Aksi Desa Mandiri Pangan (Progsi Mapan) di Kabupaten Purbalingga mulai tahun 2006. Melalui Progsi Mapan tersebut, desa Karangcegak berusaha untuk mengoptimalkan potensi bahan pangan lokal yang ada menjadi produk-produk olahan. KWT Enggal Sukses merupakan salah satu kelompok yang sampai sekarang masih aktif melakukan pengolahan jagung, terutama jagung kuning menjadi beras jagung instan dan tepung jagung. Beras jagung instan yang sudah diproduksi oleh kelompok tersebut berasal dari jagung kuning dan sudah dipasarkan di beberapa tempat, di antaranya Alfamart Semarang. Produksi beras jagung instan oleh kelompok Enggal Sukses kurang lebih $100 \mathrm{~kg}$ per bulan.

KWT Mekar Sari terletak di desa Karangjengkol, Kecamatan Kutasari, yang memiliki lahan pertanian seluas 200,06 ha, mayoritas berupa lahan kering. Dengan lahan seluas itu, jumlah jagung yang dihasilkan pada tahun 2014 sejumlah 11.259 ton. Sebagian besar penduduk desa Karangjengkol mengkonsumsi nasi jagung sebagai makanan pokok, terutama jagung putih. KWT Mekar Sari merupakan kelompok tani yang berusaha dalam pengolahan pangan dan intensifikasi lahan pekarangan. Salah satu hasil 
olahan dari KWT Mekar Sari adalah beras jagung instan dan tepung jagung dari jagung putih. Produksi beras jagung instan dan tepung jagung oleh KWT Mekar Sari masih rendah, kurang lebih $50 \mathrm{~kg}$ per bulan, walaupun sudah ada permintaan yang lebih banyak dari konsumen, namun belum bisa diwujudkan.

KWT Enggal Sukses dan KWT Mekar Sari merupakan kelompok afinitas yang bergerak dalam mengolah potensi lokal, terutama jagung. Beberapa permasalahan yang dihadapi oleh kedua kelompok tersebut adalah sebagai berikut:

- Produksi tepung jagung dan beras jagung instan mengalami kendala saat musim hujan karena pengeringan masih menggunakan cara alami yaitu dengan sinar matahari langsung. Proses pengeringan secara alami memang hemat bahan bakar, akan tetapi kelemahannya tergantung cuaca maka tidak bisa diperkirakan waktu pengeringan. Pengeringan menggunakan sinar matahari juga dapat menurunkan kualitas produk karena sulit mengatur kadar air yang diharapkan. Produk yang dikeringkan dengan cuaca yang tidak menentu juga rawan mengakibatkan tumbuhnya jamur atau kontaminan lain. Hal ini dapat diatasi dengan mengintroduksi pengering buatan (artificial drying) berupa pengering cabinet.

- Belum ada usaha untuk mengolah tepung jagung menjadi produk turunannya dalam rangka diversifikasi pangan, juga sekaligus meningkatkan produktivitas kelompok.

- Desain kemasan dan pelabelan produk yang telah dihasilkan kurang menarik dan masih sangat sederhana. Hal ini karena pengetahuan KWT dalam pengemasan dan pelabelan masih kurang. Desain kemasan yang menarik diharapkan akan memberi nilai lebih dan meningkatkan nilai ekonomi produk tersebut.

- Penyimpanan produk belum tertata dengan baik. Selama ini produk hanya disimpan di tempat terbuka sehingga produk menjadi mudah rusak, baik karena kondisi udara yang terlalu kering atau terlalu lembab, juga adanya binatang pengganggu yaitu tikus yang merusak produk.

Tujuan kegiatan pengabdian kepada masyarakat ini adalah: 1). Memperbaiki teknik pengeringan untuk menghindari kerugian karena kehilangan produk saat musim hujan, 2) Meningkatkan produktivitas kelompok dengan cara mengenalkan dan mempraktekkan produk olahan dari tepung jagung yang belum pernah dibuat, 3) Memperbaiki teknik pengemasan, pelabelan dan penyimpanan produkproduk pangan dari jagung yang telah dihasilkan.

\section{TARGET DAN LUARAN}

\section{A. Target}

Target kegiatan pengabdian kepada masyarakat ini secara umum adalah meningkatkan kualitas dan kuantitas olahan dari jagung serta meningkatkan kesejahteraan masyarakat melalui peningkatan status ekonominya, khususnya anggota KWT Enggal Sukses dan Mekar Sari di kecamatan Kutasari, Purbalingga. Target khusus kegiatan IbM ini adalah:

- Memperbaiki teknik pengeringan untuk menghindari kerugian karena kehilangan produk saat musim hujan.

- Meningkatkan produktivitas mitra, yaitu KWT Enggal Sukses dan KWT Mekar Sari

- Memperbaiki teknik pengemasan dan desain kemasan produk-produk pangan dari jagung yang telah dihasilkan

\section{B. Luaran}

Luaran yang dihasilkan dari kegiatan adalah sebagai berikut:

- Pengering buatan untuk mengeringkan produk terutama saat musim penghujan (untuk KWT Mekar Sari)

- Produksi beras jagung instan dilakukan secara kontinyu

- Kemasan produk-produk olahan jagung lebih menarik dan label dilengkapi dengan kandungan gizi produk

\section{METODE PELAKSANAAN}

Modifikasi proses pengolahan jagung berupa perendaman dan variasi ukuran akan memberikan beberapa bentuk olahan jagung [2]. Beberapa bentuk olahan sederhana dari jagung dan tepat diaplikasikan di masyarakat adalah beras jagung instan dan tepung jagung [2], [3]. Berdasarkan serangkaian penelitian dalam rangka pengembangan olahan pangan yang telah dilakukan oleh Tim peneliti (2006-2014) jagung dapat diolah menjadi berbagai produk pangan yang bergizi dan menarik, dengan teknik yang benar.

Pengembangan produksi yaitu meningkatkan kualitas dan kuantitas produk, memperbaiki teknik pengemasan dan desain kemasan, serta pemasaran produk olahan jagung merupakan hal-hal yang perlu mendapat perhatian sehingga mitra dapat memperoleh pendapatan secara maksimal. Untuk itu, perlu dibarengi dengan peningkatan pengetahuan tentang pengolahan yang benar, pengemasan dan pelabelan, sehingga dapat meningkatkan kesejahteraan anggota kelompok.

Metode pelaksanaan kegiatan dalam melaksanakan solusi permasalahan kelompok difokuskan pada bidang kegiatan permasalahan dalam bidang produksi. 


\section{A. Metode pendekatan dan kegiatan}

Ada 3 metode pendekatan yang dilakukan untuk menyelesaikan persoalan kelompok yaitu:

1) Metode penyuluhan: Materi penyuluhan yang dilakukan meliputi a) Cara memproduksi makanan yang baik untuk meningkatkan keamanan, mutu, dan umur simpan produk olahan berbasis jagung; b) Pengolahan tepung jagung menjadi mi jagung sebagai salah satu bentuk diversifikasi pangan; c) Cara pengemasan dan pelabelan produk olahan makanan yang benar dan memenuhi standar mutu; d) Macam-macam teknik pengeringan pada bahan pangan.

2) Metode praktek: Materi praktek yang dilakukan meliputi a) Praktek memproduksi makanan yang baik berdasarkan Good Manufacturing Practices (GMP) sekaligus mempraktekkan hasil olahan dari tepung jagung yaitu membuat mi jagung; b) Pengenalan penggunaan kabinet pengering sehingga kualitas beras jagung instan dan tepung jagung lebih baik dan konsisten; c) Pembuatan kemasan dan label produk yang menarik.

3) Metode pendampingan: Pendampingan dilakukan secara berkala tiap 2 minggu sekali. Pendampingan bertujuan untuk membantu tiap kelompok mencari solusi ketika menghadapi kendala dalam produksi.

\section{B. Evaluasi pelaksanaan program dan keberlanjutan program}

Guna menjamin suksesnya pelaksanaan kegiatan dan tercapainya target luaran tersebut maka disusun rancangan evaluasi yang menunjukkan adanya indikator dan standar keberhasilan.

\section{IV.HASIL DAN PEMBAHASAN}

Pemberian materi kepada kelompok yang diberikan berupa cara produksi pangan yang baik, pengenalan produk olahan dari tepung jagung berupa mi jagung, pengeringan pada produk pangan dan penjelasan tentang cara pengemasan, pembuatan label yang menarik dan penyimpanan produk pangan yang benar.

\section{A. Pengenalan cara produksi pangan yang baik}

Penerapan cara produksi pangan yang baik mampu menjamin konsistensi mutu produk yang dihasilkan. Penyuluhan cara produksi makanan yang baik dilakukan dengan menjelaskan teknik Good Manufacturing Practices $(G M P)$ pada industri pangan yang dilakukan dengan cara sebagai berikut :

- Lingkungan produksi, bangunan dan fasilitas yang digunakan untuk usaha telah layak digunakan untuk tujuan pengolahan pangan. Kriteria kelayakan tersebut dapat dilihat dari ketersediaan suplai air yang memadai dan aman digunakan (sesuai dengan persyaratan untuk air minum harian) serta bebas dari hewan liar yang dapat mengkontaminasi makanan. Lingkungan produksi juga harus selalu dalam kondisi bersih, sebelum atau sesudah proses produksi. Penataan ruang telah dipisahkan antara bagian penyimpanan bahan baku, bagian pengolahan, penyimpanan produk akhir, penyimpanan alat pendukung, dan penyimpanan bahan-bahan kimia untuk sanitasi. Pada prakteknya, ketersediaan air bersih untuk produksi sudah memadai, begitu juga dengan kebersihan tempat produksi kelompok. Masalah yang masih dihadapi adalah penataan ruang untuk produk yang masih bercampur dengan ruang produksi dan bahan mentah. Hal ini dapat mengakibatkan bahaya karena adanya kontaminasi silang dari bahan mentah, peralatan produksi dan selama proses ke produk akhir. Pemecahan masalahnya adalah dengan mempersiapkan tempat khusus untuk menyimpan produk akhir.

- Peralatan produksi yang digunakan selalu dalam keadaan bersih. Saat akan digunakan, peralatan dalam kondisi kering, dan setelah digunakan, peralatan segera dicuci dengan detergen dan disinfektan serta dikeringkan. Penggunaan peralatan produksi yang bersih sudah dilaksanakan dalam pelaksanaan proses produksi di kelompok, akan tetapi setelah digunakan dan dicuci, terkadang tidak dilakukan pengeringan pada peralatan tersebut.

- Tenaga kerja yang langsung berhubungan dengan proses pengolahan dalam kondisi sehat dan bebas dari penyakit menular ataupun gangguan kesehatan lain. Pakaian kerja khusus, penutup kepala, dan sarung tangan digunakan selama proses produksi untuk menghindari kontaminasi. Tenaga kerja telah mendapatkan pelatihan pembuatan produk, pengenalan cara produksi pangan yang baik dan pengetahuan tentang keamanan pangan sebelum menangani produksi kontinu.

- Produksi dilaksanakan dengan mengikuti standar operasional prosedur (SOP) dan selalu dilakukan pengontrolan kondisi proses selama produksi berlangsung. Standar operasional prosedur dalam produksi pangan olahan bertujuan untuk menghasilkan produk yang secara konsisten memenuhi spesifikasi mutu produk yang dipersyaratkan, termasuk tingkat keawetan atau umur simpannya. Tujuan ini dicapai dengan memperhatikan kualitas bahan baku, produk dalam proses, produk akhir, serta hal lain seperti tingkat kebersihan dan sanitasi dari tempat pengolahan dan alat serta instrument yang digunakan dalam selama proses pengolahan. Faktor-faktor penentu kualitas produk akhir digambarkan dalam bentuk diagram alir proses yang menjadi pedoman bagi pekerja yang secara langsung menangani proses pengolahan pangan.

- Kontrol mutu produk dilakukan sejak penerimaan bahan baku untuk memastikan tingkat keamanan dan kelayakan penggunaannya serta pada produk akhir 
yang meliputi analisis visual dan sensori terhadap warna, tekstur, aroma, dan rasa. Seluruh kegiatan produksi baik terkait proses ataupun kontrol mutu bahan baku dan produk akhir didokumentasikan dengan baik oleh penanggung jawab produksi [4].

- Produk dikemas dengan kemasan yang sesuai dan diberi label yang memuat : nama produk, berat bersih, komposisi produk, nilai gizi, petunjuk penggunaan dan petunjuk penyimpanan, waktu produksi,waktu kadaluwarsa, nama dan alamat produsen, kode P-IRT, dan nomer SNI (apabila sudah ada).

Penjelasan tentang GMP disertai tentang edukasi dampak penerapan GMP pada proses pengolahan pangan (Gambar 1). Adanya sosialisasi tentang GMP ini menggerakkan mitra untuk memproduksi olahan jagung sesuai standar GMP.

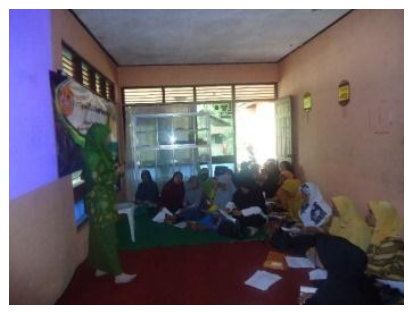

Gambar 1. Penjelasan tentang GMP

\section{B. Cara produksi olahan dari jagung}

Materi berikutnya adalah tentang pengolahan produk dari jagung meliputi beras jagung instan dan produk olahan dari tepung jagung berupa mi jagung. Beras jagung instan adalah beras jagung yang mudah dalam penyiapan dan siap dimasak menjadi nasi jagung dalam waktu relatif singkat. Karakteristik beras jagung instan terutama dipengaruhi oleh varietas jagung sebagai bahan baku dan metode pengolahannya.

Perendaman jagung putih selama 24 jam dalam pembuatan tepung jagung mengubah sifat fungsional tepung yang dihasilkan, salah satunya sifat gelatinisasi $\left.{ }^{[2}\right]$. Selain itu, proses fermentasi spontan yang terjadi selama perendaman mempunyai kelebihan yaitu mikroorganisme yang tumbuh terutama bakteri, potensial dalam mendegradasi aflatoksin yang menjadi salah satu masalah pada jagung [5]. Metode penggilingan jagung dengan metode basah, yaitu adanya proses perendaman juga akan menghasilkan tepung dengan sifat fisik dan fungsional lebih baik dibandingkan penggilingan kering [6].

Menurut [3] pada prinsipnya, proses pengolahan beras jagung instant melalui tahapan pembersihan, penggilingan, pengayakan, pemasakan dan pengeringan. Setelah kering, produk digiling kembali untuk menyeragamkan ukuran kemudian diayak dan dikemas. Bahan baku untuk pembuatan beras jagung instant ini merupakan fraksi beras yaitu yang tidak lolos ayakan 1,4 mm. Fraksi beras selanjutnya dimasak dengan perbandingan beras jagung dan air 1:4. Kadar zat gizi beras jagung instant dari jagung putih dapat dilihat pada Tabel 1.

TABEL I

KANDUNGAN GIZI BERAS JAGUNG INSTAN DARI JAGUNG PUTIH

\begin{tabular}{ll}
\hline Zat gizi & Jumlah \\
\hline Air (\% bb) & 8,100 \\
Protein terlarut (\%bk) & 2,94 \\
Protein total (\%bb) & 12,39 \\
Lemak (\%bk) & 1,25 \\
Abu (\%bb) & 0,72 \\
Karbohidrat (\%) & 77,46 \\
Energi (kkal) & 346,2 \\
\hline
\end{tabular}

Sumber: [3].

Prospek pengembangan beras jagung mempunyai potensi komersialisasi yang cukup baik. Hal ini disebabkan pemerintah sedang mencanangkan diversifikasi pangan berbahan baku lokal. Pengolahan beras jagung instant diharapkan mampu mengoptimalkan pemanfaatan jagung di bidang pangan sehingga dapat meningkatkan nilai ekonomi jagung. Pengolahan beras jagung instant menggunakan cara yang cukup sederhana sehingga dapat diaplikasikan pada skala industri menengah dan besar.

Proses pembuatan mie secara umum terdiri dari tahap pencampuran bahan, pembuatan adonan, pencetakan, pengukusan dan pengeringan. Tahap pencampuran dan pembuatan adonan bertujuan untuk membentuk adonan yang dapat dibuat lembaran dan mie dengan menambahkan air yang tepat dan mengukusnya. Untuk mendapatkan adonan yang baik dengan ciri-ciri kompak, warna homogen, penampakan mengkilat, tekstur halus, plastis dan elastis serta adonan tidak pera maupun lembek, harus diperhatikan jumlah air yang digunakan, waktu pengadukan dan suhu adonan.

Untuk meningkatkan produktivitas kelompok juga telah dirancang alat pencetak mi. Introduksi mesin pencetak mi juga membuat kelompok mitra bersemangat untuk membuat produk baru yaitu mi jagung (Gambar 2).

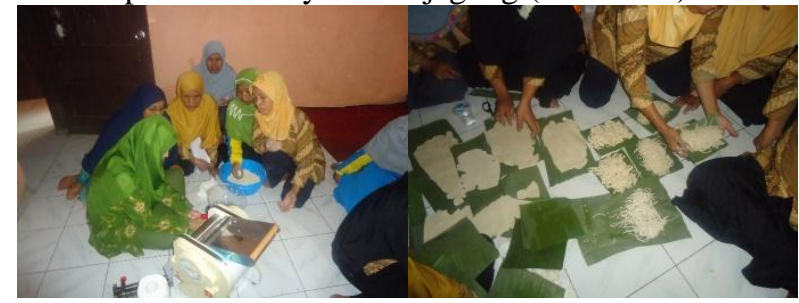

Gambar 2. Praktek pembuatan mi dari tepung jagung

Pembuatan mie dari tepung jagung memerlukan beberapa bentuk penyesuaian. Hal ini disebabkan jagung tidak dapat membentuk gluten yang mengakibatkan terbentuknya tekstur yang kompak, plastis dan elastis [1]. Pada pembuatan mi dari tepung jagung masih memerlukan tepung terigu untuk menghasilkan mi yang bersifat elastis. Bahan bahan dalam pembuatan mi jagung meliputi tepung jagung, tepung terigu, tapioka, air, CMC dan telur. Cara pembuatan mi jagung pertama-tama adalah pencampuran 
semua bahan selama 20 menit. Selanjutnya adonan dipipihkan selama berulang-ulang, setelah halus baru dipotong-potong menjadi untaian mi. Mi jagung selanjutnya dikukus selama 20-30 menit, baru diolah lebih lanjut atau dikeringkan.

\section{Penjelasan dan praktek pengeringan}

Pengeringan merupakan proses pasca panen yang bertujuan untuk menurunkan kadar air pada hasil pertanian agar memiliki umur simpan yang panjang. Pengeringan dapat diartikan sebagai proses perpindahan panas dan uap air secara simultan, yang memerlukan energi panas untuk menguapkan kandungan air yang dipindahkan dari permukaan bahan, yang dikeringkan oleh media pengering yang biasanya berupa panas. Pengeringan dalam proses pascapanen merupakan operasi yang penting, baik terhadap bahan padat maupun bahan cair.

Awalnya pengeringan dilakukan secara alami menggunakan panas matahari, namun sekarang cara tersebut dipandang kurang praktis karena cara tersebut hanya dapat dilakukan didaerah yang iklimnya panas dan kering. Apalagi hal tersebut juga memungkinkan bahan yang dijemur terkontaminasi melalui polusi dan binatang seperti tikus dan lalat. Oleh karena itu dibutuhkan alat pengering yang dapat digunakan di daerah mana saja dan tidak tergantung waktu pengeringan. Kelebihan pengeringan buatan adalah suhu dan kecepatan proses pengeringan dapat diatur seuai keinginan, tidak terpengaruh cuaca, sanitisi dan higiene dapat terjaga. Kelemahan pengeringan buatan adalah memerlukan keterampilan dan peralatan khusus, serta biaya lebih tinggi dibanding pengeringan alami [7].

Salah satu alat pengering yang banyak digunakan untuk industri adalah pengering kabinet. Pengering kabinet berbentuk persegi dan di dalamnya berisi rak-rak, yang digunakan sebagai tempat bahan yang akan dikeringkan. Beberapa alat pengering jenis itu rak-raknya mempunyai roda sehingga dapat dikeluarkan dari alat pengeringnya. Bahan diletakkan di atas rak (tray) yang terbuat dari logam dengan alas yang berlubang-lubang atau tanpa lubang. Kegunaan dari lubang-lubang ini untuk mengalirkan udara panas dan uap air. Luas rak dan besar lubang-lubang rak tergantung pada bahan yang akan dikeringkan. Apabila bahan yang akan dikeringkan berupa butiran-butiran halus, maka lubangnya berukuran kecil. Jumlah rak yang dipergunakan tergantung pada keperluan, makin besar alatnya makin banyak rak yang dibutuhkan. Pada alat pengering rak/kabinet, selain ditempatkan langsung pada rak-rak bahan dapat juga ditebarkan pada wadah lain seperti baki dan nampan [8]. Kemudian baki atau wadah disusun di atas rak yang ada dalam alat pengering. Pada umumnya pengering kabinet digunakan untuk pengeringan di dalam laboratorium, dan di dalam skala kecil serta digunakan secara komersial untuk musiman .
Fitur-fitur yang dimiliki pada alat pengering tipe rak (cabinet dryer) adalah sebagai berikut:

- Membutuhkan sedikit waktu untuk mengeringkan produk (dibandingkan dengan pengeringan alami).

- Membutuhkan lebih sedikit bahan bakar untuk mengeringkan produk.

- Berbagai macam bahan bakar seperti sabut kelapa, kayu, sekam arecanut dan limbah lainnya dapat digunakan.

- Ruang yang lebih rendah persyaratan dan waktu instalasi minimal.

- Tahan lama dengan perawatan minimal.

- Bisa dibuat dalam kapasitas bervariasi tergantung pada daerah nampan yang efektif dan kebutuhan pengguna.

- Tidak ada asap ketika pengeringan berlangsung di ruang kabinet, sehingga memastikan kualitas yang baik dari produk kering.

Perbaikan teknik pengeringan di kelompok untuk menjaga kualitas dan kontinuitas produksi, hal ini sekaligus berperan dalam memperbaiki kualitas dan kuantitas tepung jagung dan beras jagung instan. Perbaikan teknik pengeringan dilakukan dengan cara mengintroduksikan pengering kabinet (cabinet dryer) untuk membantu proses pengeringan. Pembuatan tepung jagung dan beras jagung instan dan mengalami kendala terutama saat musim hujan sehingga adanya pengering buatan sangat membantu mitra. Pengering cabinet dibuat dari stainless steel untuk menjamin keamanan produk pangan yang dihasilkan. Pengering kabinet ini sudah dipraktekkan untuk mengeringkan beras jagung instan dan tepung jagung (Gambar 3).

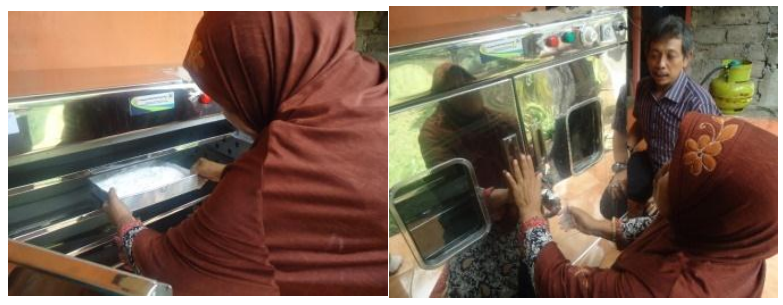

Gambar 3. Praktek dan diskusi pengeringan menggunakan kabinet pengering

\section{Perbaikan kemasan}

Kemasan mempunyai fungsi untuk melindungi produk dari kerusakan, meningkatkan daya tarik dan nilai jual produk [9]. Perbaikan kemasan dilakukan melalui pemilihan jenis bahan pengemas yang lebih cocok maupun perbaikan desain kemasan. Pada tahap ini diajarkan cara-cara membuat desain kemasan yang menarik, hal-hal apa saja yang harus ada pada sebuah pengemas serta teknik pengemasan yang benar.

Setelah produk akhir dikemas, perlu ruang penyimpanan sebelum produk tersebut didistribusikan ke konsumen. Penyimpanan produk akhir perlu dilakukan di ruang terpisah 
dari ruang produksi dan bahan baku untuk menghindari terjadinya kontaminasi silang [10]. Adanya keterbatasan fasilitas produksi di kelompok, maka penyimpanan dilakukan di almari khusus untuk menyimpan produk. Untuk itu perlu desain almari penyimpan (etalase) untuk menyimpan produk. Adanya tempat penyimpanan produk membuat kelompok semakin bersemangat untuk membuat produknya karena sekarang penyimpanan tidak terkendala gangguan selama penyimpanan, misalnya tikus.

Kegiatan Iptek bagi Masyarakat ini telah membawa beberapa perubahan bagi kelompok mitra ke hal yang lebih baik seperti tercantum pada Tabel 2. Diharapkan keberlanjutan kegiatan ini akan lebih meningkatkan kemampuan kelompok dalam meningkatkan kesejahteraannya

TABEL 2

PERUBAHAN PADA KELOMPOK SEBELUM DAN SETELAH PELAKSANAAN KEGIATAN IBM

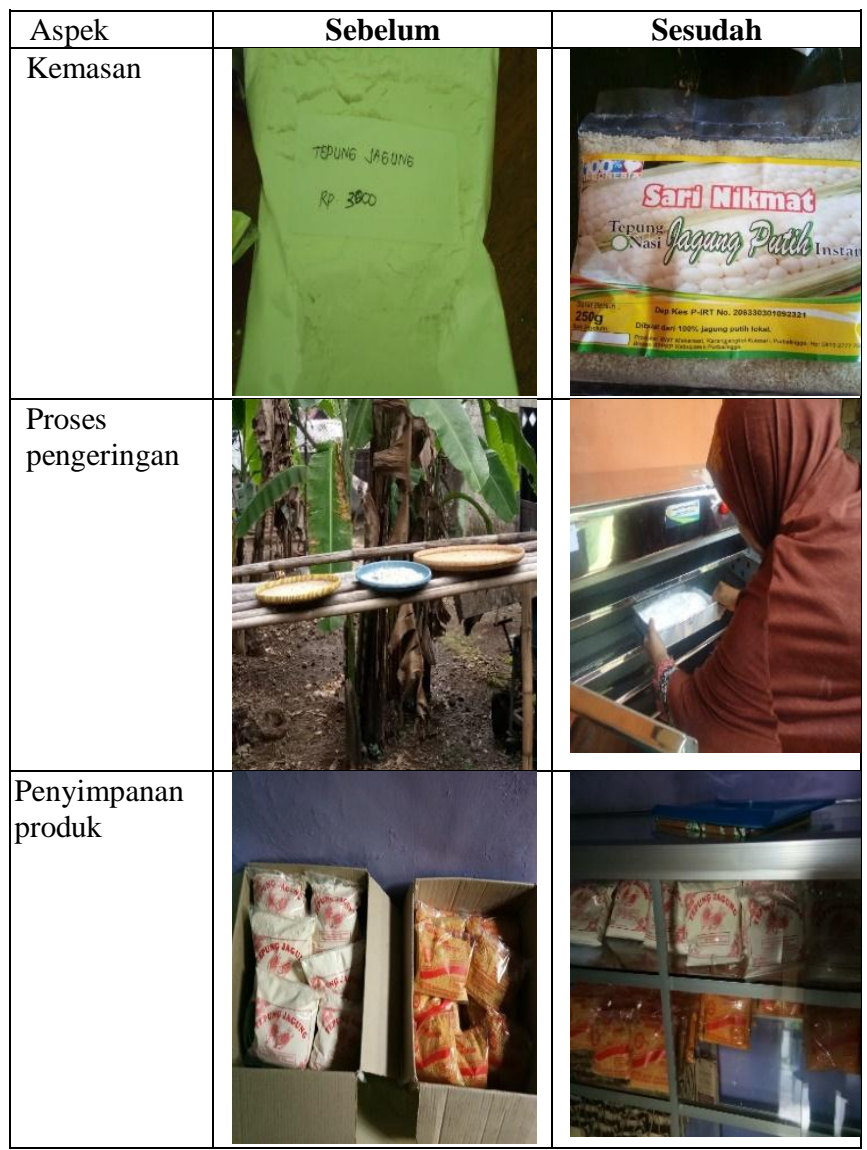

V. KESIMPULAN

Kegiatan Iptek bagi Masyarakat ini telah meningkatkan kualitas dan kuantitas hasil pengeringan dengan cara memperbaiki teknik pengeringan pada pembuatan beras jagung instan dan tepung jagung di kelompok mitra yaitu dengan adanya pengering buatan. Kelompok juga telah mengenal olahan baru dari tepung jagung, yaitu berupa mi jagung. Kemasan beras jagung instan dan tepung jagung lebih menarik dan cara penyimpanannya telah diperbaiki.

\section{UCAPAN TERIMA KASIH}

Penulis mengucapkan terima kasih Kepada Direktorat Riset dan Pengabdian Masyarakat, Kementerian Riset, Teknologi dan Pendidikan Tinggi yang telah memberikan dana melalui Program Iptek bagi Masyarakat 2018 dengan no kontrak 2088/UN23.14/PM/2018

\section{DAFTAR PUSTAKA}

[1] Aini, N., Prihananto, V. and Munarso, S.J., 2012. Characteristics of white corn noodle substitued by tempeh flour. Jurnal Teknologi dan Ind. Pangan, 23(2), pp. 179-185.

[2] Aini, N., Wijonarko, B. and Sustriawan, B., 2016. Physical, chemical, and functional properties of corn flour processed by fermentation. Agritech, 36(2), pp. 160-169.

[3] Aini, N., Prihananto, V. and Munarso, S.J., 2011. Nutritional and sensory value of corn rice instant influenced by corn immersion and tempeh substitution. Agroteknologi, 5(2), pp. 108-126.

[4] Jevsnik, M., Hiebec, V. and Raspor, P., 2008. Consumers' awareness of food safety from shopping to eating. Food Control, 19(8), pp. 737-745

[5] Yuan, M. L... Lu, Z. H., Cheng, Y. Q. and Li, L. T., 2008. Effect of spontaneous fermentation on the physical properties of corn starch and rheological characteristics of corn starch noodle. Journal Food Engineering., 85(1), pp. 12-17.

[6] Grajales-García, E. M., Osorio-Díaz, P., Goñi, I., Hervert-Hernández, D., Guzmán-Maldonado, S. H. and Bello-Pérez, L. A., 2011. Chemical composition, starch digestibility and antioxidant capacity of tortilla made with a blend of quality protein maize and black bean International Journal Molecul Science, 13(12), pp. 286-301.

[7] Margaris, D. P. and Ghiaus, A. G., 2006. Dried product quality improvement by air flow manipulation in tray dryers. Journal Food Engineering, 75 (4), pp. 542-550.

[8] Darabi, H., Zomorodian, A., Akbari, M.H. and Lorestani, A. N., 2015. Design a cabinet dryer with two geometric configurations using CFD. Journal Food Science Technology, 52(1), pp. 359-366.

[9] Silayoi, P. and Speece, M., 2007. The importance of packaging attributes: a conjoint analysis approach. European. Journal Marketing, 41(11/12), pp. 1495-1517.

[10] Mylius, S. D., Nauta, M. J. and. Havelaar, A. H., 2007. Crosscontamination during food preparation: a mechanistic model applied to chicken-borne Campylobacter. Risk Analysis, 27(4), pp. 803-813. 